\title{
High prevalence of porcine circovirus 2, porcine parvovirus, and pathogenic leptospires in mummified swine fetuses in Southern Brazil
}

\author{
Geslaine Herdt ${ }^{1}$ iD Alex Eron Maciel $^{1}$ Mathias Martins $^{1}$ iD Alexandre Alberto Tonin ${ }^{1,2}$ (iD \\ Daniela Lourdes Vanazzi ${ }^{1}$ Dyane Martins ${ }^{1}$ Núbia Deconto Baldasso $^{1}$ Lilian Kolling Girardini ${ }^{1}$ \\ Sergio Abreu Machado ${ }^{1^{*}}$ iD Paulo Eduardo Bennemann ${ }^{1}$ iD
}

${ }^{1}$ Universidade do Oeste de Santa Catarina (UNOESC), Campus II, 89820-000, Xanxerê, SC, Brasil. E-mail: sergio.machado@unoesc.edu.br. ${ }^{*}$ Corresponding author.

${ }^{2}$ Instituto Federal de Educação, Ciência e Tecnologia do Amazonas (IFAM), Manaus, AM, Brasil.

ABSTRACT: Modern swine production employs a high degree of technology and is organized in various production stages, in which reproduction is one of the most significant. However, reproductive losses associated to fetal death are still high. Fetal losses, including fetal mummification, may occur at a rate below $1.5 \%$ in a sound herd. The causes of fetal death can be very diverse, and include various infectious agents. Therefore, investigating the causes of fetal losses is important in the decision-making process related to the control and prophylaxis of the herd. The goal of this study was to carry out a molecular survey, analyzing porcine circovirus 2 (PCV2), porcine parvovirus (PPV), and pathogenic Leptospira as potential agents related to fetal death in swine farms in Southern Brazil. We collected samples from three farms with a mummified index $\geq 2.5 \%$. Fragments of brain, lung, kidney, liver, and heart were sampled for PCR analysis. Out of 100 samples examined, 87, 68, and 22 were positive for PCV2, PPV, and Leptospira spp., respectively. Moreover, we also identified coinfections with two and three pathogens in the same sample. Our findings contribute to the spreading of scientific knowledge related to infectious causes (PPV, PCV2, and pathogenic leptospires) of fetal losses in swine, as evidenced by the high frequencies of the investigated agents.

Key words: fetal losses, leptospire, PCV2, PPV, reproductive failure.

Alta prevalência de parvovírus suíno, circovírus suíno 2 e leptospiras patogênicas em fetos suínos mumificados na região Sul do Brasil

RESUMO: A produção moderna de suínos emprega um alto grau de tecnologia e é organizada em várias etapas de produção, nas quais a reprodução é uma das mais importantes. No entanto, as perdas reprodutivas associadas à morte fetal ainda são altas. Perdas fetais, incluindo mumificação, podem ocorrer em taxa abaixo de 1,5\% em rebanhos sadios. As causas da morte fetal podem ser diversas, incluindo causas infecciosas. Portanto, a investigação de causas relacionadas à ocorrência de perdas fetais é importante no processo relacionado ao controle e profilaxia do rebanho. O objetivo deste estudo foi realizar um levantamento molecular, incluindo circovírus suíno 2 (PCV2), parvovírus suíno (PPV), e leptospiras patogênicas como potenciais agentes relacionados à morte fetal em suínos no sul do Brasil. Foram coletadas amostras de três granjas com índice de fetos mumificados $\geq 2,5 \%$. Fragmentos de cérebro, pulmão, rim, figado e coração foram amostrados para análise por PCR. Das 100 amostras examinadas, 87 foram positivas para PCV2, 68 foram positivas para PPV e 22 foram positivas para Leptospira spp. Além disso, também identificamos co-infecções com dois e três patógenos em uma mesma amostra. Os resultados encontrados contribuem para a disseminação do conhecimento científico relacionado às causas infecciosas (PCV2, PPV e Leptospiras patogênicas) relacionadas às perdas fetais em suínos, assim como evidenciam a alta frequência dos agentes pesquisados.

Palavras-chave: falhas reprodutivas, Leptospiras, PCV2, perdas fetais, PPV.

Brazil is one of the most important meat producers and exporters worldwide, and its Southern region accounts for approximately $84 \%$ of all Brazilian pork exportation (ABPA, 2018). The dimensions of this pork production chain inevitably call for a stringent set of approaches towards animal health and reproductive performance (VARGAS et al., 2007). In that regard, fetal mummification has a negative impact on the total number of piglets born alive per litter (BORGES et al., 2005). According to ZANELLA, SILVEIRA \& SOBESTIANSKY (2007), fetal mummification rates of up to $1.5 \%$ are generally acceptable; however, there is an increasing number of reports indicating a steep increase in fetal mummification, with rates of over $3 \%$ being reported (data not published). Fetal mummification in swine is associated with a wide range of factors, including lack of uterine space, exposure to toxic substances, and infectious diseases (ZANELLA; SILVEIRA \& SOBESTIANSKY, 2007). 
Infections caused by porcine circovirus 2 (PCV2), porcine parvovirus (PPV), and Leptospira spp. (MORÉS; BARCELLOS \& ZANELLA, 2007) are among the most important causes of reproductive failure. Porcine circovirus type 2 is mainly linked to post-weaning multisystemic wasting syndrome (PMWS) and porcine dermatitis and nephropathy syndrome (PDNS), as well as reproductive disorders, including fetal mummification (ASANOME et al., 2008; MAES et al., 2008; MADSON et al., 2009).

Porcine parvovirus is the main infectious cause of fetal mummification in swine (ROEHE; SOBESTIANSKY \& BARCELLOS, 2007) and has been associated with reproductive failure in Brazilian swine farms for about five decades (GOUVÊIA et al., 1984). This virus infects tissues with high rates of mitosis, such as the fetus and placenta (ROEHE; SOBESTIANSKY\& BARCELLOS, 2007), and causes embryo resorption, delayed parturition, mummified fetuses, stillbirths, and perinatal death (PASCOAL et al., 2006).

Leptospirosis is a zoonosis and a widespread occupational hazard, globally associated with significant losses in porcine reproduction. It is especially important in Southern and Southeastern Brazil (LANGONI et al., 1995). Prevalent serovars, for instance Pomona, Icterohaemorrhagiae, Tarassovi, Canicola, and Bratislava (SOBESTIANSKY et al., 1999) cause embryo loss, anestrus, abortion, dystocia, reduced litters, fetal mummification, stillbirths, and runt piglets (EDWARDS, 1979). The bacteria may persist in the kidney and genital tissues for up to five months after an abortion (ELLIS \& THIERMANN, 1986).

Given the importance of these agents in swine reproduction, the goal of this study was to investigate whether PCV2, PPV, and leptospires were involved in the increasing numbers of fetal mummification in the pig farms of Southern Brazil. Samples were collected from three pig farms in the southernmost Brazilian states (Paraná, Santa Catarina, and Rio Grande do Sul) with reported occurrences of mummification $\geq 2.5 \%$. At least 30 females with different parity orders and two or more mummified fetuses from each origin were considered for this study. Fragments of brain, lung, kidney, liver and heart, and liver were collected and pooled from fetuses collected immediately after parturition and stored at $-20{ }^{\circ} \mathrm{C}$. The isolation and purification of total DNA (50$100 \mathrm{mg}$ in $10 \% \mathrm{w} / \mathrm{v}$ PBS) was achieved using silicabased spin columns according to the manufacturer's instructions (BIOPUR Kit de Extração Mini Spin Plus, Biometrix Diagnóstica Ltda., Curitiba, PR, Brasil). The PCR detection of the infectious agents was based on the amplification of conserved sequences of genes that codify for the capsid protein $(O R F 2)$ of PCV2 (RINCÓN MONROY et al., 2014) and for the nonstructural protein (NS1) of PPV (SOARES et al., 1999). Leptospires were detected through amplification of the genes $\operatorname{Lig} A$ and $\operatorname{Lig} B$ (PALANIAPPAN et al., 2005), expressed as conserved virulence factors reported only in pathogenic bacteria (MATSUNAGA et al., 2003). Polymerase chain reactions for PCV2, PPV, and Lig genes amplified fragments of 657, 330, and 468 base pairs, respectively, using a ready-to-use premixed solution (GoTaq Green Master Mix, Promega), plus 500 $\mathrm{nM}$ of primers, $2 \mu \mathrm{L}$ of template DNA, and ultrapure nuclease-free water to a final reaction volume of $25 \mu \mathrm{L}$. In each PCR run, a non-template control was included to check for contamination. In addition, positive controls (DNA samples isolated from known positive tissues) were run in parallel with unknown samples to ensure proper assay quality. Amplified products were resolved by electrophoresis on a $1 \%$ agarose gel and visualized using an intercalating stain (Unisafe Dye, Uniscience do Brasil, SP, Brazil) in a high-resolution/ sensitivity imaging system (ChemiDoc Gel Imaging System, BioRad, EUA).

A total of 100 samples were tested for the presence of PCV2, PPV, and Leptospira spp. Eighty seven percent were positive for PCV2 (87/100), 68\% were positive for PPV (68/100), and $22 \%$ were positive for pathogenic leptospires (22/100). Infection by a single agent totaled 24 samples positive for PVC2, eight samples positive for PPV, and two samples positive for Leptospira spp. Coinfection with PCV2/PPV, PCV2/ Leptospira spp., and PPV/Leptospira spp. occurred in 45,5 and 2 samples, respectively. Additionally, 13 samples were positive for all three agents investigated in this study (Figure 1).

Due to their variety, PCV2-related diseases have been extensively studied (ZANELLA; SILVEIRA \& SOBESTIANSKY, 2007). However, there are only a handful of studies suggesting the involvement of $\mathrm{PCV} 2$ in porcine reproductive failure. A Canadian report published in 1999 was the first to associate PCV2 with reproductive failure (WEST et al., 1999). ROCHA et al. (2010) reported a study in which $50.3 \%$ of samples were positive for PCV2 (stillbirths and mummified fetuses). Our results clearly indicated a high percentage of mummified fetuses positive for PCV2 (87\%). Swine populations with a high frequency of PCV2 have frequently been start-up herds with a significantly high number of susceptible gilts (YU et al., 2007). Even though vaccines against PCV2 infection are considered effective (OPRIESSNIG et al., 2008), it 


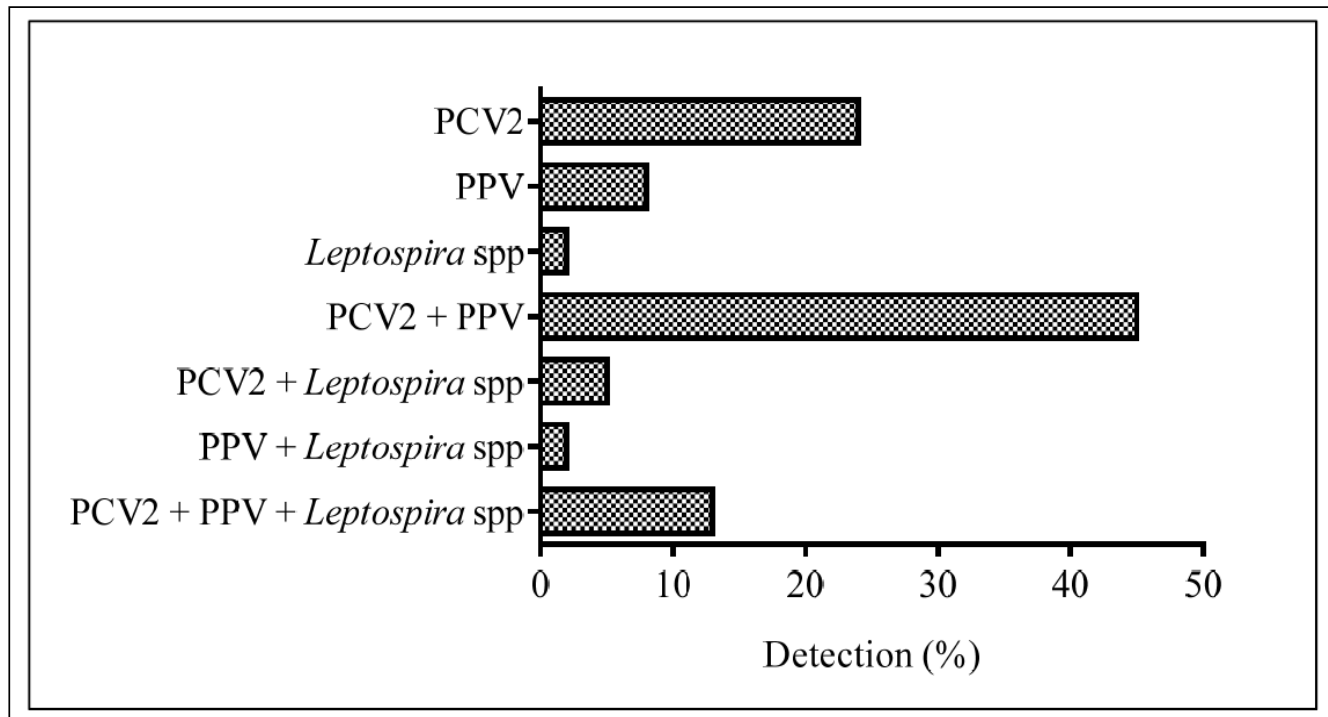

Figure 1 - Results of polymerase chain reaction (PCR) from mummified swine fetuses. Detection of porcine circovirus 2 (PCV2), porcine parvovirus (PPV) and Leptospira spp. (pathogenic leptospires) from one hundred analyzed samples. Single infections, double and triple co-infections are presented.

might be necessary to readdress vaccination protocols regarding the time point of dam immunization, which can influence the level of circulating antibodies (AFGHAH et al., 2017). OLIVER-FERRANDO et al. (2018) detected a subclinical infection in seropositive gilts and sows along with a low percentage of viremic animals before starting vaccination trials. Vaccination protocols are not yet fully standardized in Brazil, so that the maintenance of the virus in farms might be facilitated. However, it is important to emphasize that immunization without the appropriate farm management or biosafety measures does not prevent PCV2-related problems.

Our findings indicated that the molecular detection of PPV was substantial. Conversely, PESCADOR et al. (2007) reported that $2.4 \%$ of stillbirths and mummified fetuses were PPVpositive in Southern Brazilian farms, while MALDONADO et al. (2005) did not detect the presence of PPV in stillborn and aborted fetuses in Spain. This agent is ubiquitous in swine populations worldwide (SHARMA \& SAIKUMAR, 2010). Thus, widespread vaccination against PPV is regarded as an important tool to control reproductive problems (MALDONADO et al., 2005; SHARMA \& SAIKUMAR, 2010). Interestingly, our findings indicated a high frequency of PPV in mummified fetuses despite vaccination. It is noteworthy that we observed coinfection with PCV2 and PPV (45/100 samples). Coinfection with PCV2 and PPV has been associated with PMWS and abortion in naturally and experimentally infected pigs (KENNEDY et al., 2000). The PPV replicates in cells of the monocytemacrophage series and may produce immune cell dysfunction, activation, or immunosuppression, enhancing the replication of PCV2 (KENNEDY et al., 2000). However, it is not clear whether PCV2 alone is causing the reproductive failure or a coinfection with PPV could trigger these pregnancy disorders. Few vaccination protocols in Brazil use the PCV2 vaccine to prevent pregnancy losses. Thus, it might be possible that reproductive failures associated with return to estrus, early abortion, and fetal mummification have been incorrectly related to other agents or non-infectious causes. The high rate of PCV2 infection reported in our study suggested that PCV2 vaccination before breeding could be used as an important tool to decrease reproductive issues.

There are a great variety of Leptospira serovars present in swine herds worldwide, causing stillbirths, mummified fetuses, and the births of runt piglets (RAMOS et al., 2006). Fortunately, only a small number of serovars are endemic to any particular region or country, so that the clinical signs associated with leptospiral infection often include correlations with serovars. Our study did not accomplish a serovar differentiation, as we focused on the molecular detection of pathogenic leptospires. 
Although, not as prevalent as PCV2 and PPV, we observed that $22 \%$ of samples were positive for Leptospira spp. The pathogenesis of the reproductive disease is still poorly understood. Nevertheless, some authors accept that the transplacental infection that occurs during a very transient maternal leptospiremia is the sole cause of disease development (ELLIS \& THIERMANN, 1986). Despite the scarce molecular data on the detection of leptospirosis associated with reproductive issues in swine, our results are quite important. Even considering vaccination as one of most important tools to control leptospirosis in production animals (VALÉE et al., 2017), the efficacy of the swine vaccines is questionable, as they induce limited amounts of protective antibodies and are rarely produced with the strains that affect the herds (BALAKRISHNAN \& ROY, 2014). SONADA et al. (2018) published an interesting report about the efficacy of the commercial vaccine against leptospirosis. They demonstrated that three out of the five vaccines sold in Brazil for the immunization of swine (or cattle) failed to protect the vaccinated animals following a challenge with an autochthonous Leptospira strain. These results might support our findings, for all samples analyzed in our study came from regularly vaccinated herds.

Based on our results, we were able to demonstrate high frequencies of PCV2 and PPV, as well as pathogenic leptospires in mummified swine fetuses. These findings may explain the current increased rates of mummified swine fetuses observed in Southern Brazil, and indicate the need for further study on circumventing the reproductive issues caused by these agents.

\section{ACKNOWLEDGMENTS}

This work was supported by Conselho Nacional de Desenvolvimento Científico e Tecnológico (CNPq), CHAMADA MCTI/CNPQ Nº 01/2016 - UNIVERSAL - FAIXA A; Fundação de Amparo à Pesquisa de Santa Catarina (FAPESC) - CHAMADA PÚBLICA FAPESC No 09/2015 - APOIO A GRUPOS DE PESQUISA DAS INSTITUIÇÕES DO SISTEMA ACAFE and Programa de Pós-Graduação em Sanidade e Produção Animal of Universidade do Oeste de Santa Catarina (UNOESC), Xanxerê.

\section{BIOETHICS AND BIOSSECURITY COMMITTEE APPROVAL}

The authors declared, for all due purposes, the project that gave rise to the present data does not require IACUC or CEUA (Institutional Animal Care and Use Committee; Comissão de Ética no Uso de Animais) approval because it did not use LIVE ANIMALS. Thus, the authors assume full responsibility for the presented data and are available for possible questions, should they be required by the competent authorities.

\section{DECLARATION OF CONFLICT OF INTEREST}

The authors declare no conflicts of interest. The funding sponsors had no role in the design of the study; collection, analyses, or interpretation of data; writing of the manuscript; or decision to publish the results.

\section{AUTHORS' CONTRIBUTIONS}

GH, AEM, SAM performed the experiments. AAT, LKG, SAM, PEB supervised and coordinated the lab analysis. MM, SAM and PEB analyzed the results and AAT, MM, SAM and PEB writing and critically revised the manuscript. DLV, DM, $\mathrm{NCB}, \mathrm{GH}$, and AEM processed the samples.

\section{REFERENCES}

ABPA, ASSOCIAÇÃO BRASILEIRA DE PROTEÍNA ANIMAL. Produção mundial de carne suína, 2018. Available from: $<$ http:// abpa-br.com.br/storage/files/relatorio-anual-2018.pdf $>$. Accessed: Oct. 31,2018

AFGHAH, Z.et al. Ten years of PCV2 vaccines and vaccination: is eradication a possibility? Veterinary Microbiology, v.206, p.21-28, 2017. Available from: <https://www.sciencedirect.com/ science/article/pii/S0378113516304527> Accessed: Nov. 15, 2018. doi: 10.1016/j.vetmic.2016.10.002.

ASANOME, W. et al. Association between bacterial otitis and porcine circovirus 2 (PCV2) infection in pigs. Pesquisa Veterinária Brasileira, v.28, n.10, p.471-476 2008. Available from: $<$ http://www.scielo.br/scielo.php?pid=S0100$736 \times 2008001000005 \&$ script $=$ sci_abstract\&tlng $=$ pt $>$ Accessed: Oct. 10, 2018. doi: 10.1590/S0100-736X2008001000005.

BALAKRISHNAN, G \& ROY, P. Comparision of efficacy of two experimental bovine leptospira vaccines under laboratory and field. Veterinary Immunology and Immunopathology, v.159, n.2, p.11-15, 2014. Available from: <https://www.sciencedirect. com/science/article/pii/S0165242714000567> Accessed: Nov. 15, 2018. doi: 10.1016/j.vetimm.2014.03.002.

BORGES, V. et al. Risk factors for stillbirth and foetal mummification in four Brazilian swine herds. Preventive Veterinary Medicine, v.70, p.165-176. 2005. Available from: <https://www.sciencedirect. com/science/article/pii/S0167587705001133>. Accessed: Oct. 21, 2018. doi: 10.1016/j.prevetmed.2005.03.003.

EDWARDS, J.D.\& DAINES, D.A Leptospirosis outbreak in a piggery. New Zealand Veterinary Journal, v.27, n.11, p.247-248, 1979.

ELLIS, W.A.\& THIERMANN, A.B. Isolation of Leptospira interrogans serovar bratislava from sows in Iowa. American Journal of Veterinary Research, v.47, n.7, p.1458-1460, 1986. Available from: <https://europepmc.org/abstract/med/3740615>. Accessed: Nov. 15, 2018.

GOUVÊIA, A.M.G. et al. Alterações reprodutivas e prevalência de anticorpos inibidores de hemaglutinação para o parvovírus suíno no Estado de Minas Gerais. Pesquisa Veterinária Brasileira, v.4, p.17- 22, 1984.

KENNEDY, S. Reproduction of lesions of postweaning 
multisystemic wasting syndrome by infection of conventional pigs with porcine circovirus type 2 alone or in combination with porcine parvovirus. Journal of Comparative Pathology, v.122, p.9-24, 2000. Available from: <https://scholar.google.com.br/ scholar?hl=en\&as_sdt $=0 \% 2 \mathrm{C} 5 \& \mathrm{q}=$ Reproduction + of + Lesions $+\mathrm{o}$ $\mathrm{f}+$ Postweaning + Multisystemic + Wasting + Syndrome + by + Infectio $\mathrm{n}+\mathrm{of}+$ Conventional + Pigs + with + Porcine + Circovirus + Type $+2+\mathrm{Al}$ one + or + in + Combination + with + Porcine + Parvovirus \&btnG $=>$. Accessed: Nov. 15, 2018. doi: 0021-9975/00/010009.

LANGONI, H. et al. Pesquisa de aglutininas antileptospiricas em soros de ovinos no estado de São Paulo, Brasil, utilizando provas de macroaglutinação em placas e soroaglutinação microscópica. Revista Brasileira de Medicina Veterinária, v.17, n.6, p.264-268, 1995.

MADSON, D.M. et al. Reproductive failure experimentally induced in sows via artificial insemination with semen spiked with porcine circovirus type 2. Veterinary Pathology, v.46, n.4, p.707-716, 2009. Available from: <https://journals.sagepub.com/ doi/abs/10.1354/vp.08-vp-0234-o-fl>. Accessed: Oct. 11, 2018. doi: 10.1354/vp.08-VP-0234-O-FL.

MAES, D. et al. Diseases in swine transmitted by artificial insemination: an overview. Theriogenology, v.70, n.8, p.13371345, 2008. Available from: <https://www.sciencedirect.com/ science/article/pii/S0093691X08004020>. Accessed: Oct. 10, 2018. doi: 10.1016/j.theriogenology.2008.06.018.

MALDONADO, J. et al. Identification of viral pathogens in aborted fetuses and stillborn piglets from cases of swine reproductive failure in Spain. The Veterinary Journal, v.169, n.3, p.454-456, 2005. Available from: <https://www.sciencedirect.com/science/ article/pii/S1090023304001297>. Accessed: Nov. 12, 2018. doi: 10.1016/j.tvj1.2004.05.007.

MATSUNAGA, J. et al. Pathogenic Leptospira species express surface-exposed proteins belonging to the bacterial immunoglobulin superfamily. Molecular Microbiology, v.49, n.4 p.929-945, 2003. Available from: $<$ https://onlinelibrary.wiley.com/ doi/full/10.1046/j.1365-2958.2003.03619.x>. Accessed: Sep. 30, 2018. doi: 10.1046/j.1365-2958.2003.03619.x.

MORÉS, N.; BARCELLOS, D.\& ZANELLA, J. R. C. Circovirose Suína. In: SOBESTIANSKY, J.; BARCELLOS, D. Doença dos Suínos. Goiânia: Cânone Editorial, cap.7, p.213-225, 2007.

OLIVER-FERRANDO, S. et al. Exploratory field study on the effect of Porcine circovirus 2 (PCV2) sow vaccination on serological, virological and reproductive parameters in a PCV2 subclinically infected sow herd. Veterinary Research, v.14, n.130, 2018. Available from: <https://bmcvetres.biomedcentral.com articles/10.1186/s12917-018-1452-x>. Accessed: Nov. 14, 2018. doi: $10.1186 / \mathrm{s} 12917-018-1452-\mathrm{x}$

OPRIESSNIG, T. et al. Influence of maternal antibodies on efficacy of porcine circovirus type 2 (PCV2) vaccination to protect pigs from experimental infection with PCV2. Clinical and Vaccine Immunology, v.15, n.3, p.397-401, 2008. Available from: $<$ https:// cvi.asm.org/content/15/3/397.short>. Accessed: Nov. 14, 2018. doi: 10.1128/CVI.00416-07.

PALANIAPPAN, R.U. et al. Evaluation of lig-based conventional and real time PCR for the detection of pathogenic leptospires. Molecular and Cellular Probes, v.19, n.2, p.111-117, 2005 Available from: <https://www.sciencedirect.com/science/article/
abs/pii/S0890850804000970>. Accessed: Oct. 23, 2018. doi: 10.1016/j.mcp.2004.10.002.

PASCOAL, L.A.F. et al. Mortality, stillborn and fetal mummification: factors that influence the reproductive efficiency of swine. Revista Eletrônica de Veterinária, v.7, n.11, p.1-6, 2006. Available from: <http://www.veterinaria.org/revistas/redvet/ n111106/110610.pdf>. Accessed: Oct. 03, 2018.

PESCADOR, C.A. et al. Co-infection by porcine circovirus type 2 and porcine parvovirus in aborted fetuses and stillborn piglets in southern Brazil. Pesquisa Veterinária Brasileira, v.27, n.10, p.425-429, 2007. Available from: <http://www.scielo.br/scielo. php?script $=$ sci_arttext\&pid=S0100-736X2007001000007\&lng $=$ en\&nrm=iso $>$. Accessed: Nov. 15, 2018. doi: 10.1590/S0100736 X2007001000007.

RAMOS, A.C.F. et al. Influence of leptospirosis on reproductive performance of sows in Brazil. Theriogenology, v.66, n.4, p.10211025, 2006. Available from: <https://www.sciencedirect.com/ science/article/pii/S0093691X06001488>. Accessed: Nov. 15, 2018. doi: 10.1016/j.theriogenology.2005.08.028.

RINCÓN MONROY, M.A. et al. Detection and molecular characterization of porcine circovirus type 2 from piglets with Porcine Circovirus Associated Diseases in Colombia. Virology Journal, v.11, p.143, 2014. Available from: $<$ https://virologyj. biomedcentral.com/articles/10.1186/1743-422X-11-143>. Accessed: Sep. 22, 2018. doi: 10.1186/1743-422X-11-143.

ROCHA, D.L. et al. Identification of porcine circovirus type 2 and porcine parvovirus in porcine stillbirths and mummified fetuses from swine farms in Brazil. Ciência Animal Brasileira, v.11, n.3, p.600-606, 2010. Available from: <https://www.cabdirect.org/ cabdirect/abstract/20113000468 > . Accessed: Nov. 06, 2018. doi: 10.5216/cab.v11i3.5403.

ROEHE, P.; SOBESTIANSKY, J. \&BARCELLOS, D. Parvovirose. In: SOBESTIANSKY, J.\& BARCELLOS, D. Doenças dos Suínos. Goiânia: Cânone Editorial, cap.3, p.286-293, 2007.

SHARMA, R. \& SAIKUMAR, G. Porcine parvovirus- and porcine circovirus 2-associated reproductive failure and neonatal mortality in crossbred Indian pigs. Tropical Animal Health and Production, v.42, n.3, p.515-522, 2010. Available from: $<$ https:// link.springer.com/article/10.1007/s11250-009-9454-0\#citeas $>$. Accessed: Nov.15, 2018. doi: 10.1007/s11250-009-9454-0.

SOARES, R.M. et al. Detection of porcine parvovirus DNA by the polymerase chain reaction assay using primers to the highly conserved nonstructural protein gene, NS-1. Journal of Virological Methods, v.78, p.191-198, 1999. Available from: <https://www. sciencedirect.com/science/article/pii/S0166093498001773>. Accessed: Oct. 31, 2018. doi: 10.1016/S0166-0934(98)00177-3.

SOBESTIANSKY, J. et al. Clínica e patologia suína. 2.ed. Goiânia: Universidade Federal de Goiás, 1999. 464p.

SONADA, R.B. et al. Efficacy of leptospiral commercial vaccines on the protection against an autochtonous strain recovered in Brazil. Brazilian Journal of Microbiology, v.49, n.2, p.347-350, 2018. Available from: $<$ http://www.scielo.br/scielo.php?script=sci arttext\&pid $=\mathrm{S} 1517-83822018000200347 \& \operatorname{lng}=\mathrm{en} \& \mathrm{nrm}=\mathrm{iso}>$. Accessed: Nov. 15, 2018. doi: 10.1016/j.bjm.2017.06.008.

VALEÉ, E. et al. Effectiveness of a commercial leptospiral vaccine on urinary shedding in naturally exposed sheep in New 
Zealand. Vaccine, v.35, n.9, p.1362-1368, 2017. Available from: $\quad<$ https://www.sciencedirect.com/science/article/pii/ S0264410X16301785>. Accessed: Nov. 15, 2018. doi: 10.1016/j.vaccine.2016.04.037.

VARGAS, A.J. et al. Que decisão tomar frente a matrizes que apresentam falhas reprodutivas: elas merecem uma nova chance? Acta Scientiae Veterinariae, v.35, p. 57-62. 2007. Available from: <https://www.lume.ufrgs.br/bitstream/ handle/10183/13299/000601693.pdf?sequence=1>. Accessed: Oct. $30,2018$.

WEST, K.H. et al. Myocarditis and Abortion Associated with Intrauterine Infection of Sows with Porcine Circovirus 2. Journal of Veterinary
Diagnostic Investigation, v.11, n.6, p.530-532, 1999. Available from: $<$ https://journals.sagepub.com/doi/abs/10.1177/104063879901100608> . Accessed: Oct. 24, 2018. doi: 10.1177/104063879901100608.

YU, S. et al. Porcine circovirus type 2 (PCV2) distribution and replication in tissues and immune cells in early infected pigs. Veterinary Immunology and Immunopathology, v.11, n.3, p.261-272, 2007. Available from: <https://www.sciencedirect. com/science/article/pii/S0165242706003254>. Accessed: Oct. 14, 2018. doi: 10.1016/j.vetimm.2006.11.006.

ZANELLA, E.; SILVEIRA, P.R.S\& SOBESTIANSKY, J. Falhas reprodutivas. In: BARCELLOS, D.; SOBESTIANSKY, J. Doenças dos Suínos. P.541-575. Goiânia: Cânone Editorial. 2007. 